Research article

\title{
An analysis of environmental incidents for a national Antarctic program
}

\author{
Shaun T. Brooks ${ }^{\mathrm{a}, *}$, Julia Jabour ${ }^{\mathrm{a}}$, Andy J. Sharman ${ }^{\mathrm{b}}$, Dana M. Bergstrom ${ }^{\mathrm{b}}$ \\ a Institute for Marine and Antarctic Studies, University of Tasmania, Hobart, Tasmania, Australia \\ b Australian Antarctic Division, 203 Channel Highway, Kingston, Tasmania, Australia
}

\section{A R T I C L E IN F O}

\section{Article history:}

Received 2 February 2018

Accepted 6 February 2018

Available online xxx

\section{Keywords:}

Antarctica

Incidents

Accidents

Spills

Biosecurity

Footprint

\begin{abstract}
A B S T R A C T
Research stations in Antarctica are concentrated on scarce ice-free habitats. Operating these stations in the harsh Antarctic climate provides many challenges, including the need to handle bulk fuel and cargo increasing the risk of environmental incidents. We examined 195 reports of environmental incidents from the Australian Antarctic Program, spanning six years, to investigate the impacts and pathways of contemporary environmental incidents. Fuel and chemical spills were most common, followed by biosecurity incursions. The majority of reports were assessed as having insignificant actual impacts. Either the incidents were small, or active, rapid response and mitigation procedures minimised impact. During the period only one spill report (40001) was assessed as a 'high' impact. This is despite over 13 million litres of diesel utilised. The majority of incidents occurred within the existing station footprints. The pathways leading to the incidents varied, with technical causes predominately leading to spills, and procedural failures leading to biosecurity incursions. The large number of reports with inconsequential impacts suggest an effective environmental management system with a good culture of reporting environmental incidents. Our findings suggest that the key to continual improvement in an ongoing environmental management system is to learn from incidences and take action to prevent them occurring again, with an end-goal of minimising the residual risk as much as possible.
\end{abstract}

(C) 2017

\section{Introduction}

Extreme cold, wind, altitude and isolation make Antarctica one of the most challenging operational environments on Earth. Antarctic Treaty nations demonstrate their commitment to protect the Antarctic environment through adherence to the Protocol on Environmental Protection (the Environmental Protocol - Article 3.1). Despite such commitments, human activities and incidences in Antarctica are known to affect biota, degrade the environment and habitat, contaminate substrates, and impact wilderness and aesthetic values (Hull and Bergstrom, 2006; Tin et al., 2009). The potential significance of many environmental incidents increases because Antarctic program activities are focussed in terrestrial areas, which constitute just $0.34 \%$ (or less) of the continent (Burton-Johnson et al., 2016; Terauds and Lee, 2016), and most stations are located in the $\sim 0.05 \%$ of terrestrial Antarctica within $2 \mathrm{~km}$ of the coast (Hull and Bergstrom, 2006). The impacts of contamination and disturbance are compounded further by slow natural recovery rates in the cold environment (Ferguson et al., 2004; Bargagli, 2008; Polmear et al., 2015).

The main forum for reporting environmental incidents associated with national Antarctic program operations is through the Council of Managers of National Antarctic Programs (COMNAP). In 1999,

\footnotetext{
* Corresponding author.

Email address: stbrooks@utas.edu.au (S.T.imothy Brooks)
}

COMNAP released an assessment of environmental emergencies from a voluntary survey of 17 National Antarctic Programs (COMNAP, 1999). During a ten-year period (1988-1998), 133 incidents which had 'potential' to result in adverse environmental impacts or required an emergency response had been reported (COMNAP, 2000). The majority of incidents were hydrocarbon spills (93), predominately of diesel fuel (69) with 30 in excess of 1000 litres (1) (COMNAP, 2000). There were also 10 transport-related incidents where the vehicles/aircraft were irretrievable. COMNAP (2002) updated this assessment with a further 58 environmental incidents reported between 1999 and 2002.

Environmental incidents have continued to occur since 2002. At least 14 vessels have sunk or run aground, including the sinking of the tourist vessel MV Explorer in the Bransfield Strait in 2008 (Darby, 2010; ASOC, 2012; Baxendale, 2016). The ship was carrying 2100001 of hydrocarbons, with an undetermined amount polluting surrounding marine environments. Onshore spills have also continued to occur; some with quantities up to 250001 (NZAS, 2003). Hydrocarbon contamination around stations suggest that smaller spills are also common and widespread (Bargagli, 2008; Klein et al., 2012; Raymond et al., 2016). Such contamination is known to impact Antarctic biota and habitat function (Raymond et al., 2016).

Heavy metal contamination is readily detected in substrates around active and abandoned stations (Santos et al., 2005; Bargagli, 2008; Guerra et al., 2013). While more evidence is needed on the di- 
rect effects of heavy metal on Antarctic ecosystems (Claridge et al., 1995; Santos et al., 2005; Bargagli, 2008; Guerra et al., 2013), they may have synergistic impacts when combined with hydrocarbon contamination (Stark et al., 2003).

The treatment of waste has improved since the adoption of the environmental protocol by most Antarctic nations. Despite reports of waste dispersal issues now being rare, they are inevitably associated with operational accidents. Within the past 10 years these have included two catastrophic station fires, with known contamination occurring (Russia, 2009; BBC, 2012; Guerra et al., 2013). Remote area aircraft accidents have also occurred, with certain levels of waste deposition (ABC, 2010; AAD, 2013; ATSB, 2015). Near-shore resupply incidents including barges overturning and ships running aground also occur (e.g. Brazil, 2012; AAD, 2016), with a potential for release of waste and pollution (e.g. abrasion and release of anti-fouling treatments into the local environment). There is also ongoing legacy waste associated with the presence of old tip sites and waste management practices from prior to the environmental protocol.

Introductions of non-native species into Antarctic environments have also been reported (Hughes et al., 2009, 2011; Houghton et al., 2014). Research has demonstrated that national program and tourist operations are vectors for non-native species and propagules (Whinam et al., 2005; Hughes et al., 2009; Chown et al., 2012; IAATO, 2012; Houghton et al., 2014). Incursions of non-native flora and fauna are occurring, with increasing ranges into natural habitats (Hughes and Worland, 2010; Olech and Chwedorzewska, 2011; Chwedorzewska et al., 2014). Although most species arriving are outside their climatic range, the diversity of species arriving (Whinam et al., 2005; Hughes et al., 2011; Houghton et al., 2014), and warming temperatures in Antarctic regions (Mulvaney et al., 2012), increases the possibility of establishment (Frenot et al., 2005; Chown et al., 2012; Hughes et al., 2012; Molina-Montenegro et al., 2014; Pertierra et al., 2016; Lee et al., 2017).

Negative impacts on Antarctic vertebrate wildlife have been demonstrated from disturbance associated with general Antarctic program operations (Coetzee and Chown, 2016). Although there has been no evidence of introduced disease (Grimaldi et al., 2010), individual animal deaths (IAATO, 2011a; IAATO, 2011b; IAATO, 2012), the ease of possible transfer (Curry et al., 2002), and discovery of antibodies for common avian disease in wildlife near stations (Miller et al., 2008) have raised concern of the risk (Kerry and Riddle, 2009).

Reports of accidental spatial impacts on the terrestrial environment (i.e. landscape or habitat degradation and expansion of physical footprint) are scarce (Poland et al., 2003), but known to have occurred (Tin et al., 2009). Monitoring of popular tourism landing sites and within the vicinity of stations shows incidental impacts such as compaction of soils and trampling of vegetation (see: Tejedo et al., 2009, 2016; Tin et al., 2009). There is however limited baseline data to distinguish any cumulative increase with new incidents. Despite this lack of evidence, with 267979 tourism visitor landings in 2015-16, and 109 COMNAP-listed national facilities across Antarctica (COMNAP, 2016; IAATO, 2017), it is expected cumulative incidental impacts occur.

Thus incidents resulting in contamination or disturbance are known to occur, are not uncommon, and impact the Antarctic environment and its values; but how do they occur, how often do they have more than an inconsequential impact, and are they preventable? This paper presents the analysis of the pathways and impacts of contemporary environmental incidents for a large national Antarctic program, and the first overview examination in general since COMNAP (2002). In 2002, Australia became the first Antarctic Treaty party to implement a ISO14001 based Environmental Management System
(EMS) for all of its operations (Maggs, 2002). As part of the systematic approach to environmental management under its EMS, the Australian Antarctic Division (AAD) developed an online reporting system (Incidents, Hazards and Improvement Suggestions Reporting System -IHIS) to aid the continual improvement of its operations. Staff are required to $\log$ incidents and near misses regardless of size. This reporting culture provides a sizable dataset to analyse. Here we examine six years of data from this system looking for trends in the cause of environmental incidents and lesson learned that might be valuable for Australia and other operators in Antarctica.

\section{Materials and methods}

The AAD introduced IHIS, an intranet-based system, to log incidents, near misses, and improvement suggestions. Within IHIS an environmental incident is defined as 'an unexpected occurrence that has had, or could have, an adverse effect on the environment'. Each IHIS report activates a tiered response and subsequent corrective actions (See Fig. 1). The intent of IHIS within the EMS, is the fast reporting of information to allow timely mitigation action, as well as enabling the review of existing practices to prevent future occurrences across all operations.

IHIS reporting is required as soon as practicable following an incident (Fig. 1). Each report in IHIS initially captures the type of incident, details about the incident, location, and initial description of impact (if applicable) directly from the people engaged in the activity in which an incident has occurred. After submission, each IHIS report is classified by type (incident, near miss or improvement) and given two ratings; first on potential and then actual level of impact by AAD's environmental managers. The incident's features are also reviewed against quantifiable parameters (for example: litres of fuels spilled), and within a qualitative consequence scale (Table S1) to derive an impact rating. Impact ratings range from NI (no applicable impact), through Insignificant, Low, Medium, High, to Critical. We reviewed data on environmental incidents from these reports occurring between 31 December 2009-18 February 2016 (6.2 years).

One hundred and ninety-five reports of incidents occurring across the four Australian Antarctic and sub-Antarctic stations, as well as en route post-quarantine biosecurity incursions detected at sea, were examined. Reports of near misses with no actual impact were not examined. Twelve reports were contemporary impacts from incidents occurring prior to the review period. These reports were included for their cause, but separated (marked historic) for their impact data to delineate them from incidents occurring during the review period. We classified the incident reports along the following categories: biosecurity incursion, bird strike, fuel/chemical spills, waste, wildlife disturbance, and footprint (spatial disturbance impacts).

Additional supporting data of fuel/chemical spills were also compiled including estimated spill quantity data from an existing unpublished review (Frost, 2013) and unpublished data. Estimates were not available or applicable for some incidents. Incident reports with estimated quantities were merged into the dataset to enable analysis of the fuel/chemical spills. Data on fuel quantities used by the main station plant and equipment (vehicles, boilers, incinerators, and generators) during the review period at the stations were compiled from Australian Department of the Environment State of the Environment Reporting Indicators 56, 57, and 58 (fuel usage of generators and boilers, incinerators, and vehicles respectively) (Ratcliffe, 2001, updated 2014; Ratcliffe et al., 2001, updated 2014b, a). These were accessed and retrieved from the Australian Antarctic Data Centre (data.aad.gov.au). 


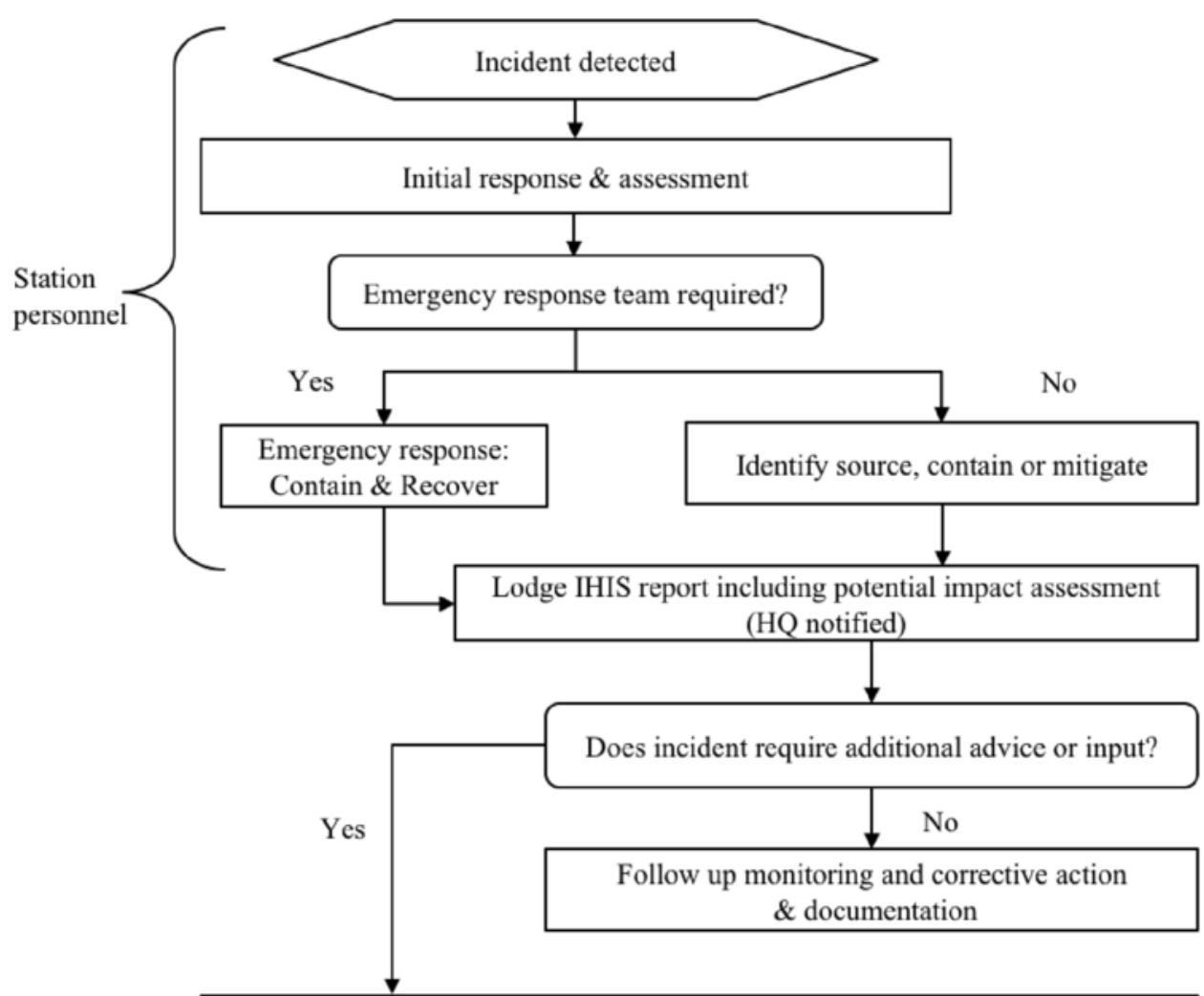

Incident investigation \& rapid assessment or environmental impact and risks. Identify \& document mitigation actions

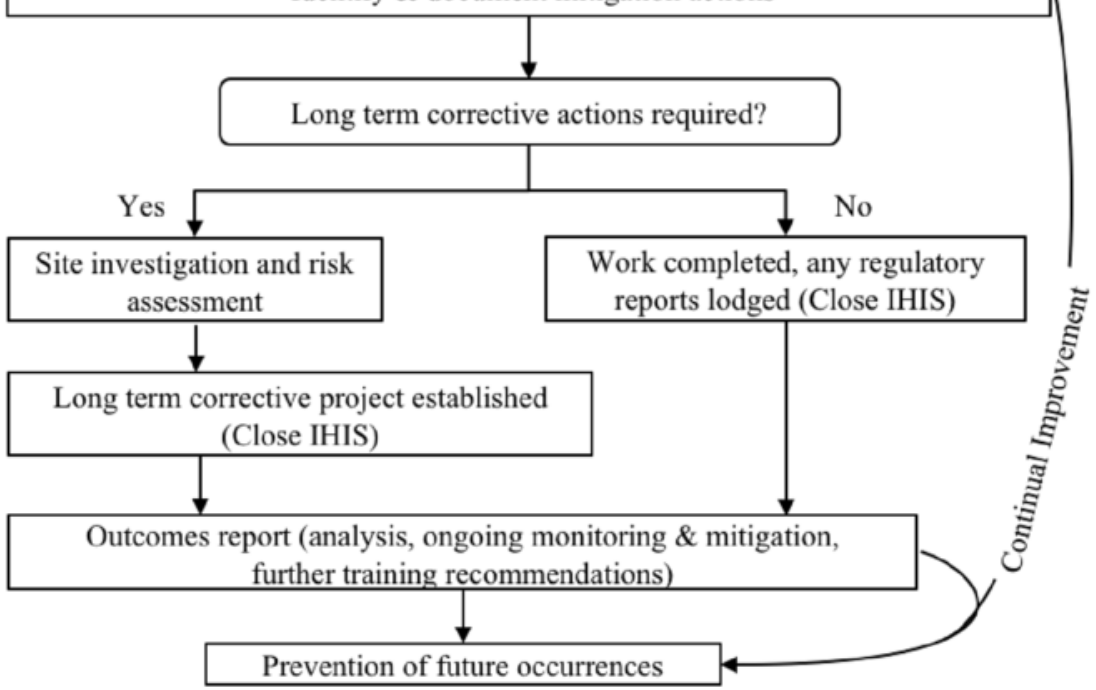

Fig. 1. IHIS Response flow chart.

To develop an understanding of probable cause we categorised each incident into either physical operational failures, or procedural failures. From these two broad categories, five suggested primary causes were developed to provide informative pathways. To allocate a primary cause to an incident, a key criterion differentiating each cause was given, followed by a series of guiding criteria (Table 1). These were intended to assist avoiding semantic differences between the causes. Each incident report was then assessed against these criteria to determine their suggested cause. Pathways identifying potential trends were defined and possible actions to avoid future recurrences were identified.

Incident reports were collated by classification, level of impact and suggested cause, and then where the incident occurred. This was included to indicate the contribution of incidents to the overall cumulative impact within an Antarctic station area. All reports were assessed whether they occurred within the immediate station footprint or the broader associated operating area. This information was then used to provide the proportion of incident reports occurring within the station areas. 
Table 1

Incident-cause selection criteria.

\begin{tabular}{|c|c|c|}
\hline Cause & Fundamental Criteria & Supporting Criteria \\
\hline Failure of process & $\begin{array}{l}\text { Processes exist, were } \\
\text { implemented, but didn't } \\
\text { prevent. }\end{array}$ & $\begin{array}{l}\text { Sufficient application/diligence of } \\
\text { process. } \\
\text { Process ineffective/insufficient. } \\
\text { Insufficient resourcing to } \\
\text { effectively apply procedures. } \\
\text { Process effective - downstream. } \\
\text { Unexpected pathway or outcome. } \\
\text { Program's contractors failed } \\
\text { process. } \\
\text { Unforeseen changes in logistics. }\end{array}$ \\
\hline $\begin{array}{l}\text { External to } \\
\text { program's } \\
\text { processes }\end{array}$ & $\begin{array}{l}\text { No existing process in } \\
\text { place to prevent. }\end{array}$ & $\begin{array}{l}\text { Unforeseen/unpredictable event. } \\
\text { Plausible but not practical to } \\
\text { prevent. } \\
\text { Process possible - not yet created. } \\
\text { A result of a third party's actions. } \\
\text { Historic cause (procedural or } \\
\text { operational). } \\
\text { Event of nature. }\end{array}$ \\
\hline $\begin{array}{l}\text { Failure of plant } \\
\text { and equipment }\end{array}$ & Unforeseeable failure. & $\begin{array}{l}\text { Preventative measures not } \\
\text { practical. } \\
\text { Possible to reduce, but } \\
\text { prohibitive to eliminate. } \\
\text { Caused by adverse conditions. }\end{array}$ \\
\hline $\begin{array}{l}\text { Failure of } \\
\text { maintenance }\end{array}$ & Foreseeable failure. & $\begin{array}{l}\text { Preventative measures possible. } \\
\text { Failure due to normal wear. } \\
\text { Could have been reasonably } \\
\text { prevented. }\end{array}$ \\
\hline Operator error & $\begin{array}{l}\text { Operator failed to follow } \\
\text { established procedures. }\end{array}$ & $\begin{array}{l}\text { Failure of workmanship. } \\
\text { Failure to apply pre-existing } \\
\text { processes. } \\
\text { Insufficient application/diligence } \\
\text { of process. } \\
\text { Due to inattention. }\end{array}$ \\
\hline
\end{tabular}

Case studies were included to further examine the process and response to incidents.

\section{Results and discussion}

Given the logistics, harsh conditions, quantities of equipment, personnel and fuel transported by the Australian Antarctic program, very few environmental incidents resulted in substantive environmental impacts. There were also no 'Critical' rated incidents over the six-year study period (Table S1).

There were 14 bird strikes reported with static objects (poles, antenna, and tensioned cables), windmills (both turbines and measuring instruments) and a helicopter. Unfortunately bird strikes are an expected impact of aerial infrastructure (Manville, 2005; Drewitt and Langston, 2006). The environmental impact assessment for the Mawson Station wind turbines identified birds striking the rotating vanes as a risk (Riddle in Kerry and Riddle, 2009). Bird strikes are difficult to completely mitigate against, but because of the crucial role these structures provide in Antarctica, rationalisation and reengineering of aerial infrastructure on Antarctic stations may reduce the risk (e.g. Longcore et al., 2008). A further two wildlife incidents involving curious elephant seals interacting with station infrastructure on Macquarie Island occurred. As clarity exists as to the cause of these 16 incidents, they are excluded from the remainder of the discussion.

The suggested cause of the remaining 179 incident reports varied, with Failure of Process providing the highest proportion at $44 \%$ (79) of total incidents. Failure of plant and equipment came next at $20 \%$ (35), then Operator error $17 \%$ (30), and Failure of maintenance $11 \%$ (20), and External to the Australian Antarctic program's processes at $8 \%$ (15). Divided by broad classification the causation varied, Failure of plant and equipment was the major contributor to fuel/chemical spill incidents, whereas Failure of process was the major contributor to waste and especially biosecurity (Fig. 2).

\subsection{Fuel and chemical spills}

The Australian Antarctic program has had a long-term focus on hydrocarbon contamination and remediation research initiating with Kerry (1993), thus we anticipated (and found) a high level of diligence in reporting spills. Indeed, most fuel/chemical spills were of small quantities. On the reports in which quantities were recorded (47/79), $50 \%$ were less than 101 , and $85 \%$ were less than the COMNAP (2008) reporting requirements $(>2001)$. The small volumes corresponded with $75 \%$ of IHIS reports having no (NI) or insignificant actual impacts. Although fuel spill mean estimated quantities were skewed by large, outlying events median values were low: diesel fuel 10131 (7.51 median), drummed fuel 991 (151), glycol 91 (51), hydraulic fluid 31 (21), and lubricating oil $11(0.51)$. This is encouraging because 132788171 of diesel was used across boilers, generators, incinerators and vehicles over the time period examined (Ratcliffe, 2001, updated 2014; Ratcliffe et al., 2001, updated 2014a, b). This demonstrates relatively successful fuel handling and storage. However, of the remaining $25 \%, 6 \%(5)$ of spill incidents were rated as having Medium or High actual impact (see case studies below).

Four medium and one high spill incidents occurred during the period we examined. Four of these are further detailed in Hayhow (2013); McWatters et al. (2016); Raymond et al. (2016), with the remaining report initiated due to detecting historical hydrocarbon contamination at Macquarie Island; the exact source of this contamination has not been determined. The high rated spill, caused by operator error, occurred at Casey Station in 2015, directly upslope of a previously remediated medium spill from 2012 (see Raymond et al., 2016). This spill contaminated about $800 \mathrm{~m}^{2}$ of soil with over 40001 of fuel, as well as the recontamination of an area already being remediated (McWatters et al., 2016). Active mitigation of the spill occurred on discovery utilising expertise developed from the previous spill, including pioneering reuse of bioremediated soils as backfill during the clean-up (McWatters et al., 2016).

Of these five medium/high spills, only one occurred outside the station precinct. A 600 litre spill occurred within the catchment of Lake Dingle, a hypersaline lake frequented by wildlife and of scientific interest in the Vestfold Hills, when a helicopter needed to jettison

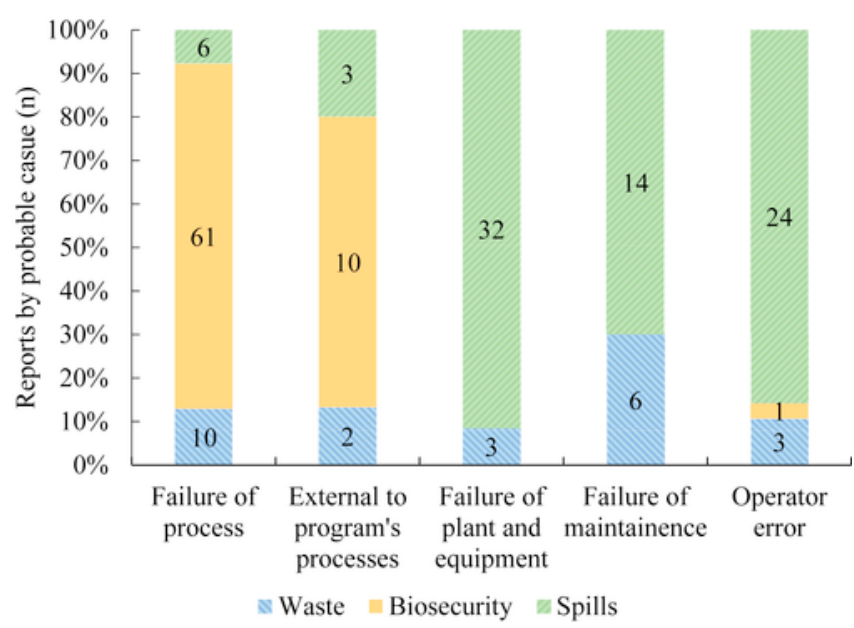

Fig. 2. Number of total incidents broken down into probable cause (wildlife and footprint incidents excluded). 
a load of three fuel drums to maintain stability (Raymond et al., 2016). Due to the location of this spill, mitigation was particularly resource and labour intensive with 168 tonnes of soil excavated and moved to station by helicopter for remediation (Raymond et al., 2016).

During the six-year period, diesel fuel incidents made up 57\% of the 79 spill reports, with the remaining spread across other fluid types (Fig. 3). This is $17 \%$ lower than found collectively by COMNAP (2000). The diesel losses were also just $0.07 \%$ (97511) of the total consumed during the period (132788171). There was also no known ship to shore refuelling incidents; generally considered the most hazardous activity by the program. This potentially indicates progress in fuel handling since the COMNAP survey and the release of their advisory Fuel Manual (COMNAP, 2008). Furthermore, it reflects a shifting focus from large spills (as they reduce in number) to small scale incidents that in many cases are hard to eliminate entirely and are well reported within the Australian program (noting the COMNAP diesel proportions may be affected by operators only reporting larger quantity spills).

The causes this study allocated to all spill incidents were dominated $(88 \%)$ by operational factors: operator error, failure of maintenance, and failure of plant equipment; where equipment was not operated correctly, was insufficiently maintained, or something had broken (Fig. 2). COMNAP (2000) also reported spills as operational failures, with $51 \%$ human error and $49 \%$ mechanical failure, but did not consider them in the context of procedural failures.

A number of inherent properties of fuel handling and use in Antarctica lead to operational factors being the primary cause of fuel-based environmental incidents. First is the large volumes of fuel/ chemicals handled in varied ways increases the likelihood of operational errors, second is the immediate dispersals of fluids into the environment as not all transfer and storage infrastructure can be contained within bunds. For example, 12 incidents were hydraulic fluid leaks from ruptured lines on large vehicles, which are unpredictable and likely to occur outside of contained areas. If fuel/chemical spill incidents for other programs reflect the causes found in Fig. 2, initially targeting improvements to reduce plant/equipment failures and operator error through timely replacement of equipment and improved training may provide the greatest return. However, it worthy to consider that is not always possible to avoid incidents through a maintenance program. Maintenance of aging infrastructure become increasingly difficult and not all failures can be anticipated and thus included in a maintenance program. The extreme environmental con-

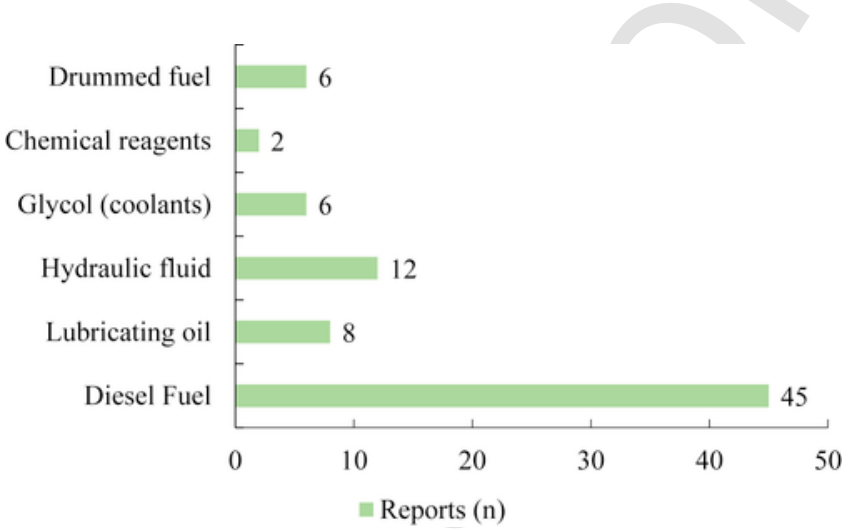

Fig. 3. Number of fuel/chemical spill reports by fluid type [modelled on figure in COMNAP (1999), noting this figure includes spills below COMNAP reporting requirements]. ditions can present unexpected problems in equipment which will not be flagged until it occurs.

In the 79 fuel/chemical spill reports examined, 65 were rated as potential to be greater than insignificant (i.e.: low, medium, and high impacts), but only 14 were reported by environmental managers as having those actual impacts. Two key reasons explain this discrepancy. The first is these reports included spills within bunded areas that were entirely contained. The second is immediate response and mitigation action have prevented many spills from causing environmental harm, through the use of spill kits or the complete removal of spills if they have been contained within small volumes of snow. This minimisation may be attributable to measures developed through the AAD's EMS and the COMNAP Fuel Manual (2008).

In response to these and other spills, as well as meeting the general goal of improved environmental performance, the AAD has conducted internal and commissioned independent reviews of fuel handling. In addition to the environmental damage the larger spills have cost the program substantially in terms of on-ground clean-up and remediation, as well as in-direct costs in displacement of scientific research and loss of opportunity. From the reviews, ongoing improvements to address the types of root causes identified in this study are now in place including replacing risk-prone infrastructure as well as updating and implementing a range of procedures and administrative measures. This reflects an active process in improved environmental management aligned with the principles of an EMS.

\subsection{Biosecurity incursions}

Concern for Antarctic biosecurity has gained increasing prominence since the 1991 environmental protocol. There has been substantial growth in knowledge of the field (e.g. Frenot et al., 2005; Chown et al., 2012) as well as the development of, and adaptation of biosecurity measures (Hulme et al., 2012; Hughes and Pertierra, 2016). Over the last two decades, the AAD has supported research, the development of mitigation methods and culture change in its organisation. Screening of cargo has occurred since 2002 (Whinam et al., 2005), a state-of-the-art cargo and biosecurity facility, with associated procedural changes, opened in 2013 (Australia, 2013), an organisation-wide agreed approach to biosecurity was adopted in 2014 (AAD, Internal report 2014), and the AAD played a role developing the Committee for Environmental Protection's Non-Native Species Manual (CEP, 2016). Furthermore, the AAD has had the additional impetus for heightened biosecurity awareness, procedures, and facilities to secure the A $\$ 25$ million public investment in the successful Macquarie Island Pest Eradication Program (Australia, 2014). Of particular focus has been the prevention of re-introduction of rodents to Macquarie Island through its activities.

Most biosecurity incursions with the IHIS reports (50 from 72) were detected in controlled indoor environments, such as invertebrates in foodstuffs followed by mitigation (removal), thus demonstrating a continuum of vigilance and action beyond the pre-departure quarantine procedures in Australia. These incursions were also relatively rare; with over 105 tonnes of food transported to the Australian stations in the 2016/17 season (N. Tennant, Personal Communication, 13/7/2017). Ninety-four percent of these incidents were assessed as actual low impact or less (Fig. 4), however $40 \%$ of incidents presented a medium or high potential impact, due to the risk of establishment in local ecosystems. An example of this is the 2014 detection of non-native collembola within a hydroponics facility at Davis Station, most likely introduced on growing media and thus undetected in the procedural biosecurity screening processing (failure of process) (Australia, 2017). The rapid response following detection and IHIS 
Journal of Environmental Management xxx (2018) xxx-xxx

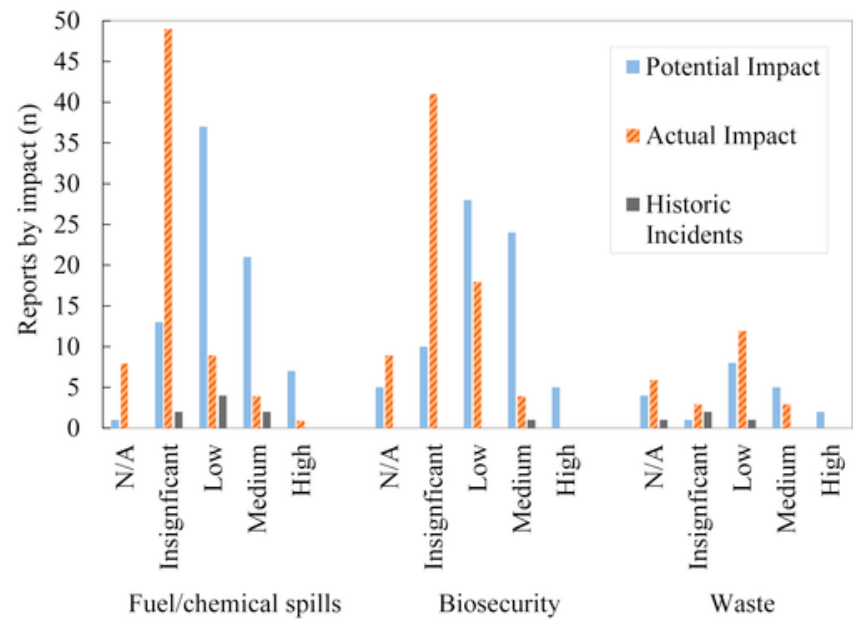

Fig. 4. Level of impact reported from individual incidents, noting 'potential' and 'actual' are listed concurrently.

reporting of this incursion hopefully has prevented the establishment of the species in the natural environment (Bergstrom et al. in press). The majority of biosecurity reports ( 71 of 72 incidents) were procedural failures in the initial steps of cargo preparation and transport (Fig. 2). However that they were found, indicates that the final step of biosecurity procedures, early detection, was achieved. Furthermore many IHIS reports were detections of dead non-native species. Dead insects, for example, may have been killed by treatment such as fogging during cargo process.

The heightened state of awareness is reassuring, but the effectiveness and difficulty in achieving 100\% effectiveness of those procedures for a large Antarctic program means there will be pathways for these incidents to continue to occur (see also Houghton et al., 2014). The placement of multiple barriers to non-native species is probably the most effective way to mitigate this risk and these include high levels of biosecurity awareness and vigilance on stations by all personnel to ensure early detection and rapid response to any incursions (e.g. Bergstrom et al., 2017).

\subsection{Waste dispersal}

Waste dispersal only constituted $13.5 \%(n=24)$ of total incident reports during this period (Fig. 2.). This is contrasting to historic waste; which has been estimated to present a similar scale of contamination as hydrocarbons in the Antarctic environment (Snape et al., 2001). The low number of reports may be attributed to improved awareness, policies, and procedures around cleaning up waste (COMNAP, 2013). Waste dispersal incidents may also be perceived as having less immediacy compared to spills, or go unnoticed, or just not occur as often as other types of incidences.

Waste reports had the least difference between the reported potential and actual impacts of all classifications (Fig. 4). Furthermore, the proportion of incidents incurring an impact greater than insignificant was two times higher than biosecurity, and three times of fuel/chemical spills, demonstrating waste dispersal as a genuine pathway for environmental impacts.

The underlying causes of waste incidents reflected the range of materials, with a distributed spread across the causes equally split between operational and procedural (Fig. 2). The highest contributing cause was failure of process (inappropriate or inadequate storage of material), at $42 \%$ of reports. The incidents involved a range of materials, with a bias towards drums and plastic wrapping and covers. Re- ports commonly involved waste dispersal due to unexpectedly adverse weather or failure of securing fasteners. A current AAD waste management project is focused on range of operational changes, further procedural implementation, and improved cultural awareness of the issue to reduce further waste dispersal incidents from occurring.

\subsection{Other incidents}

Incidents with a primary impact of an unintentional expansion of the footprint of stations were only reported on four occasions. These included undesirable placement of storage and track formation. We acknowledge other forms of impact reported (i.e. contamination, waste dispersal) also contribute to a station's footprint (see: Brooks et al., submitted). The four disturbance footprint incidents were rated as NI (2), low, and high actual impacts, with two attributed to failure of processes, and two for operator error. These were omitted from the figures due to the low number. Given the cumulative nature of disturbance footprint, and the limited literature on landscape disturbance in Antarctica (see: Tin et al., 2009), it is expected further expansion has occurred. Assessing a station's footprint baseline, such as Brooks (2014), may prompt operational awareness, as well as enabling further detection of such incidents.

\subsection{Incident locations}

Incidents occurred within station limits for the large majority of reports; $73 \%$ of total, (divided by classification: $73 \%$ of fuel $/$ chemical spills, $78 \%$ of biosecurity, and $67 \%$ of waste reports) occurred within this area. The remainder occurred within the broader operating areas associated with each station and reflects the hub and spoke model of human activities in Antarctica (Hull and Bergstrom, 2006). As station limits are the focal point of Antarctic activity, the majority of incidents occurring within them is expected. The location of these incidents are important, as on-station incidents may add to, or be undetectable above, the existing long-term disturbance footprint of the stations. The minority of incidents on the periphery or external to station limits, however, have the potential to expand the footprint of Antarctic operations. Although this dataset did not contain sufficient information to quantify the footprint of these incidents, it does draw attention to a heightened risk to the environment for field activities.

\section{Conclusions}

These results show small scale environmental incidents have continued to be relatively common in the Australian Antarctic Program since the COMNAP (1999) survey. Although this was expected due to the challenges of Antarctic operations, this analysis of incidents associated with a large national program should assist other Antarctic operators in meeting their objectives and obligations under the environmental protocol. Incidents are generally caused by a number of mechanisms, but there were distinct pathways for the two highest reported incidents: fuel/chemical spills and biosecurity incursions. The pathways of fuel/chemical spills occurred due to operational failures, while most biosecurity incidents were consistently process failures, with processes either not fully implemented or not yet created. The pathways that led to fuel/chemical spill incidents, primarily operational failures, are technical in nature due to their reliance on equipment for prevention, with a range of measures required to reduce them further, including improvements in quality and design of manufactured equipment for use in Antarctic environments.

In the case of biosecurity, although the processes technically failed as non-native incursions occurred, process-driven awareness 
has also led to early detection and eliminated actual impact at the stations. Just two known non-native species establishments were detected during this period; both on Macquarie Island, which is under the jurisdiction of the Tasmanian government and therefore outside the direct control of the AAD (Pertierra et al., 2016, DPIPWE \& University of Queensland unpublished data). Reduction in further process failures may be achieved by regular review and audits of procedures for effectiveness and achievability, and further training and awareness for the operator's staff and their suppliers.

Fuel and chemical spills in these reports had the most impacts on the environment through quantity and severity. Fuel spills are a dominant source of pollutants at all stations (Bargagli, 2008) and this result supports the body of work on the risk of spills in Antarctica, as well as the AAD's dedicated remediation research. Although the current climatic gradient has mostly provided protection up until recently from non-native species impacts, biosecurity incursions are an emerging threat to the region, and national programs are a proven unintentional vector for intercontinental translocation (with the exception of the sub-Antarctic) (Chown et al., 2012). We recognise that major non-natives species incursion, potentially can alter ecosystems permanently and recommend that all Antarctic programs should take measures to ensure the risk is appropriately addressed.

Incidents contributing to the expansion of the disturbance footprint are expected to occur more often, but may not be recognised as an 'incident', or there are no means currently for it to constitute an incident (i.e. incomplete footprint baseline measurements). In the case of these findings it is suggested, with the exception of spills and fuel contamination, environmental incidents in the Australian Antarctic Program over the six years studied have contributed to an existing cumulative environmental impact but play a smaller role than the footprint from planned activities and pre-environmental protocol practices.

The results found by this study were derived from reports made by Antarctic expeditioners. As such, the data is indicative (rather than robust) of what is occurring, and more importantly, what expeditioners are aware of and therefore are more likely to detect and report. The reporting of 119 insignificant incidents during this period indicates that operators have high awareness of the IHIS system. This culture of awareness, and emphasised no-blame approach, is important in preventing major incidents, but increases the overall number of reports. This awareness may also be heightened in less disturbed areas away from station limits, disproportionately increasing off-station reports. These reports are also vulnerable to what an individual or organisation considers an incident.

\subsection{Future directions for improvement in environmental stewardship}

The use of an incident reporting system, as part of an EMS, has demonstrated that expeditioners working in the Australian Antarctic program have a high level of environmental awareness. Underlying cause analysis allows managers to focus on pathways to reduce the number of further incidences (repeat occurrences), acknowledging while some pathways may require a straightforward change, others may be highly technical and cost prohibitive. All categories examined (failure of process, external to programs processes, operator error, failure of maintenance, failure of plant and equipment) can be incrementally improved through a hierarchy of controls to address risks by looking at elimination, substitution, engineering controls and administrative controls. While this approach is more commonly applied to hazards and safety it is also useful when investigating the underlying cause of significant environmental incidents. The key to continual improvement in an ongoing environmental management system is to learn from incidences and take action to prevent them occurring again with an end-goal of reducing the residual risk to as low as possible. This is an ongoing process at the AAD. That even small incidents are being recorded suggests that a good environmental protection culture is also well established with the Australian Antarctic Program and this analysis provides a baseline for future comparisons. Analysis of incidents is an inherent component of the AAD's operations and its EMS and is intended to support continually improved maintenance and replacement schedules.

\section{Acknowledgments}

The Australian Antarctic Division provided access to data from their incident and hazards register (IHIS). Jacqui Allan provided assistance with accessing this data. Ewan McIvor provided comment on an earlier version of the manuscript. ST Brooks is supported by an Australian Government Research Training Program Scholarship.

\section{Appendix A. Supplementary data}

Supplementary data related to this chapter can be found at https:// doi.org/10.1016/j.jenvman.2018.02.024.

\section{References}

AAD, 2013. Australian Antarctic Division. Vale: Kenn Borek Air Crew http://www. antarctica.gov.au/magazine/2011-2015/issue-24-june-2013/in-brief/ vale-kenn-borek-air-crewAccessed 18 May 2016

AAD, Australian Antarctic Division, 2016. Aurora Australis Aground at Mawson Station. http://www antarctica.gov.au/news/2016/

aurora-australis-aground-at-mawsonAccessed 18 May 2016

ABC, Australian Broadcasting Corportation, 2010. No Survivors after Antarctic Chopper Crash - ABC News. http://www.abc.net.au/news/2010-10-30/ no-survivors-after-antarctic-chopper-crash/2317480Accessed 18 May 2016.

ASOC, Antarctic and Southern Ocean Coalition, 2012. Follow-up to Vessel Incidents in Antarctic Waters, IP 53.

ATSB, Australian Transport Safety Bureau, 2015. Controlled Flight into Terrain Involving Aérospatiale AS350B2 VH-hrq. Australian Transport Safety Bureau.

Australia, 2013. Australia's New Antarctic Cargo and Biosecurity Operations Facility, ATCMXXXVI - BP009, 20 - 29 May 2013. Antarctic Treaty Secretariat, Brussels.

Australia, 2014. Macquarie Island: from Rabbits and Rodents to Recovery and Renewal Commonwealth of Australia. Department of Environment.

Australia, 2017. Detection and Eradication of a Non-native Collembola Incursion in a Hydroponics Facility in East Antarctica, IP 54, Antarctic Treaty Consultative Meeting XL. Antarctic Treaty Secretariat, Beijing.

Bargagli, R., 2008. Environmental contamination in Antarctic ecosystems. Sci. Total Environ. 400, 212-226. https://doi.org/10.1016/j.scitotenv.2008.06.062.

Baxendale, R., 2016. Burned Chinese Ship Sinks in Antarctic. http://www. theaustralian.com.au/news/latest-news/burned-chinese-ship-sinks-in-antarctic/ story-fn3dxix6-1226626785203Accessed 18 May 2016.

BBC, British Broadcasting Corporation, 2012. Two die in fire at Brazil's Antarctic research station - News. http://www.bbc.com/news/ world-latin-america-17168526Accessed 18 May 2016.

Bergstrom, D.M., Sharman, A., Shaw, J.D., Houghton, M., Janion-Scheepers, C., Achurch, H., Terauds, A., 2017. Detection and eradication of a non-native Collembola incursion in a hydroponics facility in East Antarctica. Biol. Invasions https:// doi.org/10.1007/s10530-017-1551-9.

Brazil, 2012. Comandante Ferraz Station: Oil Barge Incident, IP 65, Antarctic Treaty Consultative Meeting XXXV. Antarctic Treaty Secretariat, Hobart.

Brooks, S.T., 2014. Developing a standardised approach to measuring the environmental footprint of Antarctic research stations. J. Environ. Assess. Pol. Manag. 16, 1450037https://doi.org/10.1142/s1464333214500379.

Brooks, S.T., Jabour, J., Bergstrom, D.M., submitted. What is 'footprint' in Antarctica: proposing a set of definitions. Antarct. Sci., in press.

Burton-Johnson, A., Black, M., Fretwell, P.T., Kaluza-Gilbert, J., 2016. An automated methodology for differentiating rock from snow, clouds and sea in Antarctica from Landsat 8 imagery: a new rock outcrop map and area estimation for the entire Antarctic continent. Cryosphere 10, 1665-1677. https://doi.org/10.5194/ tc-10-1665-2016. 
CEP, Committee for Environmental Protection, 2016. Non-native Species Manual 2nd Ed.. Secretariat for the Antarctic Treaty.

Chown, S.L., Huiskes, A.H.L., Gremmen, N.J.M., Lee, J.E., Terauds, A., Crosbie, K., Frenot, Y., Hughes, K.A., Imura, S., Kiefer, K., Lebouvier, M., Raymond, B., Tsujimoto, M., Ware, C., de Vijver, B.V., Bergstrom, D.M., 2012. Continent-wide risk assessment for the establishment of nonindigenous species in Antarctica. Proc. Natl. Acad. Sci. U.S.A. 109, 4938-4943. https://doi.org/10.1073/pnas. 1119787109 .

Chwedorzewska, K.J., Giełwanowska, I., Olech, M., Molina-Montenegro, M.A., Wódkiewicz, M., Galera, H., 2014. Poa annua L. in the maritime Antarctic: an overview. Polar Rec. 51, 637-643. https://doi.org/10.1017/s0032247414000916.

Claridge, G., Campbell, I.B., Powell, H., Amin, Z., Balks, M.R., 1995. Heavy metal contamination in some soils of the McMurdo Sound region, Antarctica. Antarct. Sci. 7, 9-14. https://doi.org/10.1017/S0954102095000034.

Coetzee, B.W., Chown, S.L., 2016. A meta-analysis of human disturbance impacts on Antarctic wildlife. Biol. Rev. Camb. Phil. Soc. 91, 578-596. https://doi.org/10. $1111 /$ brv. 12184.

COMNAP, Council of Managers of National Antarctic Programs, 2002. Working Paper on an Assessment of Environmental Incidents Arising from Activities in Antarctica WP27, ATCM XXV Warsaw Poland.

COMNAP, Council of Managers of National Antarctic Programs, 2013. Committee for Environmental Protection CLEAN-UP MANUAL, ATCM XXXVI Final Report, Resolution 2, (Brussels, Belgium).

COMNAP, Council of Managers of National Antarctic Programs, 1999. An Assessment of Environmental Emergencies Arising from Activities in Antarctica, Working Paper 16 for XXIII Antarctic Treaty Consultative Meeting, Lima, 24 May-4 June 1999.

COMNAP, Council of Managers of National Antarctic Programs, 2000. Revised Working Paper on an Assessment of Environmental Emergencies Arising from Activities in Antarctica wp005, SATCM XII - CEP III. Antarctic Treaty Secretariat, The Hague, Netherlands.

COMNAP, Council of Managers of National Antarctic Programs, 2008. COMNAP Fuel Manual, Version 1.0. COMNAP Secretariat, Hobart.

COMNAP, Council of Managers of National Antarctic Programs, 2016. Antarctic Facilities List, 27 July 2016 https://www.comnap.aq/Information/SiteAssets/ SitePages/Home/Antarctic_Facilities_List_27July16.pdf.

Curry, C.H., McCarthy, J.S., Darragh, H.M., Wake, R.A., Todhunter, R., Terris, J., 2002. Could tourist boots act as vectors for disease transmission in Antarctica?. J. Trav. Med. 9, 190-193. https://doi.org/10.2310/7060.2002.24058.

Darby, A., 2010. Ady Gil and whalers Both at Fault for Collision: Inquiry. Sydney Morning Herald http://www.smh.com.au/environment/whale-watch/ ady-gil-and-whalers-both-at-fault-for-collision-inquiry-20101118-17y8u.htmlAccessed 15 July 2017.

Drewitt, A.L., Langston, R.H., 2006. Assessing the impacts of wind farms on birds. Ibis $148,29-42$.

Ferguson, S.H., Woinarski, A.Z., Snape, I., Morris, C.E., Revill, A.T., 2004. A field trial of in situ chemical oxidation to remediate long-term diesel contaminated Antarctic soil. Cold Reg. Sci. Technol. 40, 47-60. https://doi.org/10.1016/j. coldregions.2004.05.008.

Frenot, Y., Chown, S.L., Whinam, J., Selkirk, P.M., Convey, P., Skotnicki, M., Bergstrom, D.M., 2005. Biological invasions in the Antarctic: extent, impacts and implications. Biol. Rev. 80, 45-72. https://doi.org/10.1017/s1464793104006542.

Frost, L., 2013. Fuel Spills - Review and Analysis from 1980s to March 2013. Department of Sustainability, Environment, Water, Population and Communities, Australian Government, Unpublished report.

Grimaldi, W., Jabour, J., Woehler, E.J., 2010. Considerations for minimising the spread of infectious disease in Antarctic seabirds and seals. Polar Rec. 47, 56-66. https://doi.org/10.1017/s0032247410000100.

Guerra, M.B.B., Neto, E.L., Prianti, M.T.A., Pereira-Filho, E.R., Schaefer, C.E.G.R., 2013. Post-fire study of the Brazilian Scientific Antarctic Station: toxic element contamination and potential mobility on the surrounding environment. Microchem. J. 110, 21-27. https://doi.org/10.1016/j.microc.2013.01.007.

Hayhow, C., 2013. My Antarctic Adventure, Wednesday 27th February 2013 http:// craighayhow.blogspot.com.au/2013/03/wednesday-25th-february-2013.htmlAccessed 18 April 2017.

Houghton, M., McQuillan, P.B., Bergstrom, D.M., Frost, L., van den Hoff, J., Shaw, J., 2014. Pathways of alien invertebrate transfer to the Antarctic region. Polar Biol. 39, 23-33. https://doi.org/10.1007/s00300-014-1599-2.

Hughes, K.A., Convey, P., Maslen, N.R., Smith, R.I.L., 2009. Accidental transfer of non-native soil organisms into Antarctica on construction vehicles. Biol. Invasions 12, 875-891. https://doi.org/10.1007/s10530-009-9508-2.

Hughes, K.A., Lee, J.E., Tsujimoto, M., Imura, S., Bergstrom, D.M., Ware, C., Lebouvier, M., Huiskes, A.H.L., Gremmen, N.J.M., Frenot, Y., Bridge, P.D., Chown, S.L., 2011. Food for thought: risks of non-native species transfer to the Antarctic region with fresh produce. Biol. Conserv. 144, 1682-1689. https://doi.org/10.1016/ j.biocon.2011.03.001.
Hughes, K.A., Pertierra, L.R., 2016. Review: evaluation of non-native species policy development and implementation within the Antarctic Treaty area. Biol. Conserv. 149-159, https://doi.org/10.1016/j.biocon.2016.03.011.

Hughes, K.A., Worland, M.R., 2010. Spatial distribution, habitat preference and colonization status of two alien terrestrial invertebrate species in Antarctica. Antarct. Sci. 22, 221-231. https://doi.org/10.1017/s0954102009990770.

Hughes, K.A., Worland, M.R., Thorne, M.A.S., Convey, P., 2012. The non-native chironomid Eretmoptera murphyi in Antarctica: erosion of the barriers to invasion. Biol. Invasions 15, 269-281. https://doi.org/10.1007/s10530-012-0282-1.

Hull, B., Bergstrom, D., 2006. Antarctic Terrestrial and Limnetic Ecosystem Conservation and Management, Trends in Antarctic Terrestrial and Limnetic Ecosystems. Springer, 317-340.

Hulme, P.E., Pyšek, P., Winter, M., 2012. Biosecurity on thin ice in Antarctica. Science 336, 1102-1104. https://doi.org/10.1126/science.336.6085.1102-b.

IAATO, International Association of Antarctica Tour Operators, 2012. Report of the International Association of Antarctica Tour Operators 2011-12, IP 036, Antarctic Treaty Consultative Meeting XXXV. Antarctic Treaty Secretariat, Hobart.

IAATO, International Association of Antarctica Tour Operators, 2017. 2015-2016 Number of Visitors (tourists, staff and crew) per site per vessel - Peninsula and Continental Sites (6 Sheets Total). http://iaato.org/documents/10157/1444539/ 2015-2016+Number + of + Visitors $+\% 28$ tourists $\% 2$ Cstaff + and + crew $\% 29$ per + Site + per + Vessel + 8b2b402b-65e8-4150-b1e3-90e89d26a501.

Kerry, E., 1993. Bioremediation of experimental petroleum spills on mineral soils in the Vestfold Hills, Antarctica. Polar Biol. 13, 163-170. https://doi.org/10.1007/ BF00238926.

Kerry, K.R., Riddle, M., 2009. Health of Antarctic wildlife: a Challenge for Science and Policy. Springer Science \& Business Media.

Klein, A.G., Sweet, S.T., Wade, T.L., Sericano, J.L., Kennicutt, M.C., 2012. Spatial patterns of total petroleum hydrocarbons in the terrestrial environment at McMurdo Station, Antarctica. Antarct. Sci. 24, 450-466. https://doi.org/10.1017/ s0954102012000429.

Lee, J.R., Raymond, B., Bracegirdle, T.J., Chades, I., Fuller, R.A., Shaw, J.D., Terauds, A., 2017. Climate change drives expansion of Antarctic ice-free habitat. Nature 547, 49-54. https://doi.org/10.1038/nature22996.

Longcore, T., Rich, C., Gauthreaux, S.A., 2008. Height, guy wires, and steady-burning lights increase hazard of communication towers to nocturnal migrants: a review and meta-analysis. Auk 125, 485-492. https://doi.org/10.1525/auk.2008.06253

Maggs, T., 2002. AAD Achieves International Environment Standard. Australian Antarctic Magazine.

Manville, A.M., 2005. Bird Strikes and Electrocutions at Power Lines, Communication Towers, and wind Turbines: State of the Art and State of the Science-next Steps toward Mitigation. 1051-1064, USDA Forest Service General Technical Report PSW-GTR-191.

McWatters, R.S., Wilkins, D., Spedding, T., Hince, G., Raymond, B., Lagerewskij, G., Terry, D., Wise, L., Snape, I., 2016. On site remediation of a fuel spill and soil reuse in Antarctica. Sci. Total Environ. 963-973. https://doi.org/10.1016/j. scitotenv.2016.07.084

Miller, G.D., Watts, J.M., Shellam, G.R., 2008. Viral antibodies in south polar skuas around Davis Station, Antarctica. Antarct. Sci. 20, 455-461. https://doi.org/10. 1017/S0954102008001259.

Molina-Montenegro, M.A., Carrasco-Urra, F., Acuña-Rodríguez, I., Oses, R., Torres-Díaz, C., Chwedorzewska, K.J., 2014. Assessing the importance of human activities for the establishment of the invasive Poa annua in Antarctica. Polar Res. 33, 21425. https://doi.org/10.3402/polar.v33.21425.

Mulvaney, R., Abram, N.J., Hindmarsh, R.C.A., Arrowsmith, C., Fleet, L., Triest, J., Sime, L.C., Alemany, O., Foord, S., 2012. Recent Antarctic Peninsula warming relative to Holocene climate and ice-shelf history. Nature 489, 141-144. https:// doi.org/10.1038/nature11391.

NZAS, 2003. McMurdo oil spill. J. N. Z. Antarct. Soc. 20.

Olech, M., Chwedorzewska, K.J., 2011. Short note: the first appearance and establishment of an alien vascular plant in natural habitats on the fore field of a retreating glacier in Antarctica. Antarct. Sci. 23, 153-154. https://doi.org/10.1017/ s0954102010000982.

Pertierra, L.R., Baker, M., Howard, C., Vega, G.C., Olalla-Tarraga, M.A., Scott, J., 2016. Assessing the invasive risk of two non-native Agrostis species on sub-Antarctic Macquarie Island. Polar Biol. 39, 2361-2371. https://doi.org/10. 1007/s00300-016-1912-3.

Poland, J.S., Riddle, M.J., Zeeb, B.A., 2003. Contaminants in the Arctic and the Antarctic: a comparison of sources, impacts, and remediation options. Polar Rec. 39, 369-383. https://doi.org/10.1017/s0032247403002985.

Polmear, R., Stark, J.S., Roberts, D., McMinn, A., 2015. The effects of oil pollution on Antarctic benthic diatom communities over 5 years. Mar. Pollut. Bull. 90, 33-40. https://doi.org/10.1016/j.marpolbul.2014.11.035.

Ratcliffe, G., 2001, updated 2014. Monthly Incinerator Fuel Usage of Australian Antarctic Stations. Australian Antarctic Data Centre - CAASM Metadata. (http:// data.aad.gov.au/aadc/metadata/metadata_redirect.cfm?md=/AMD/AU/SOE_ incinerator_fuel_usage). 
Ratcliffe, G., Sheers, R., Bonnice, J., 2001, updated 2014a. Monthly Fuel Usage of the Generator Sets and Boilers at Australian Antarctic Stations. Australian Antarctic Data Centre - CAASM Metadata. http://data.aad.gov.au/aadc/metadata/metadata redirect.cfm?md=/AMD/AU/SOE_generator_boiler_fuel_usage.

Ratcliffe, G., Sheers, R., Bonnice, J., 2001. Monthly Total of Fuel Used by Vehicles at Australian Antarctic Stations. updated 2014b, Australian Antarctic Data Centre, Australian Antarctic Data Centre - CAASM Metadata http://data.aad.gov.au/aade/ metadata/metadata_redirect.cfm?md=/AMD/AU/SOE_vehicle_fuel_usage.

Raymond, T., King, C.K.․, Raymond, B., Stark, J.S., Snape, I., 2016. Oil pollution in Antarctica. In: Fingas, M. (Ed.), Oil Spill Science and Technology, second ed. Elsevier, pp. 759-804

Russia, 2009. International Cooperation in the Antarctic as an Important Argument for Provision of Safety of Operations and Investigations in the Region, IP 047, ATCM XXXII CEP XII. Antarctic Treaty Secretariat, Baltimore.

Santos, I.R., Silva-Filho, E.V., Schaefer, C.E., Albuquerque-Filho, M.R., Campos, L.S., 2005. Heavy metal contamination in coastal sediments and soils near the brazilian Antarctic station, king george Island. Mar. Pollut. Bull. 50, 185-194. https://doi.org/10.1016/j.marpolbul.2004.10.009.

Snape, I., Riddle, M.J., Stark, J.S., Cole, C.M., King, C.K., Duquesne, S., Gore, D.B., 2001. Management and remediation of contaminated sites at Casey Station, Antarctica. Polar Rec. 37, 199-214. https://doi.org/10.1017/S0032247400027236.
Stark, J.S., Snape, I., Riddle, M.J., 2003. The effects of petroleum hydrocarbon and heavy metal contamination of marine sediments on recruitment of Antarctic soft-sediment assemblages: a field experimental investigation. J. Exp. Mar. Biol. Ecol. 283, 21-50. https://doi.org/10.1016/S0022-0981(02)00449-5.

Tejedo, P., Benayas, J., Cajiao, D., Albertos, B., Lara, F., Pertierra, L.R., Andres-Abellan, M., Wic, C., Lucianez, M.J., Enriquez, N., Justel, A., Reck, G.K., 2016. Assessing environmental conditions of Antarctic footpaths to support management decisions. J. Environ. Manag. 177, 320-330. https://doi.org/10.1016/j.jenvman. 2016.04.032.

Tejedo, P., Justel, A., Benayas, J., Rico, E., Convey, P., Quesada, A., 2009. Soil trampling in an Antarctic Specially Protected Area: tools to assess levels of human impact. Antarct. Sci. 21, 229-236. https://doi.org/10.1017/s0954102009001795.

Terauds, A., Lee, J.R., 2016. Antarctic biogeography revisited: updating the Antarctic conservation biogeographic regions. Divers. Distrib. 22, 836-840. https://doi.org/ 10.1111/ddi.12453.

Tin, T., Fleming, Z.L., Hughes, K.A., Ainley, D.G., Convey, P., Moreno, C.A., Pfeiffer, S., Scott, J., Snape, I., 2009. Impacts of local human activities on the Antarctic environment. Antarct. Sci. 21, 3-33. https://doi.org/10.1017/S0954102009001722.

Whinam, J., Chilcott, N., Bergstrom, D.M., 2005. Subantarctic hitchhikers: expeditioners as vectors for the introduction of alien organisms. Biol. Conserv. 121 207-219. https://doi.org/10.1016/j.biocon.2004.04.020. 